\title{
Front Matter: Volume 7104
}

, "Front Matter: Volume 7104," Proc. SPIE 7104, Remote Sensing for Agriculture, Ecosystems, and Hydrology X, 710401 (29 October 2008); doi: 10.1117/12.817158

SPIE. Event: SPIE Remote Sensing, 2008, Cardiff, Wales, United Kingdom 


\title{
PROCEEDINGS OF SPIE
}

\section{Remote Sensing for Agriculture, Ecosystems, and Hydrology $X$}

\author{
Christopher M. U. Neale \\ Manfred Owe \\ Guido D'Urso \\ Editors
}

16-18 September 2008

Cardiff, Wales, United Kingdom

Sponsored by

SPIE Europe

Cooperating Organisations

EARSC_European Association of Remote Sensing Companies

EOS-European Optical Society

Technium OpTIC (United Kingdom)

NASA-National Aeronautics and Space Administration (United States)

WOF-Welsh Opto-electronics Forum (United Kingdom)

Published by

SPIE

Volume 7104 
The papers included in this volume were part of the technical conference cited on the cover and title page. Papers were selected and subject to review by the editors and conference program committee. Some conference presentations may not be available for publication. The papers published in these proceedings reflect the work and thoughts of the authors and are published herein as submitted. The publisher is not responsible for the validity of the information or for any outcomes resulting from reliance thereon.

Please use the following format to cite material from this book:

Author(s), "Title of Paper," in Remote Sensing for Agriculture, Ecosystems, and Hydrology X, edited by Christopher M. U. Neale, Manfred Owe, Guido D'Urso, Proceedings of SPIE Vol. 7104 (SPIE, Bellingham, WA, 2008) Article CID Number.

ISSN 0277-786X

ISBN 9780819473356

Published by

SPIE

P.O. Box 10, Bellingham, Washington $98227-0010$ USA

Telephone +1 3606763290 (Pacific Time) · Fax +1 3606471445

SPIE.org

Copyright (c) 2008, Society of Photo-Optical Instrumentation Engineers

Copying of material in this book for internal or personal use, or for the internal or personal use of specific clients, beyond the fair use provisions granted by the U.S. Copyright Law is authorized by SPIE subject to payment of copying fees. The Transactional Reporting Service base fee for this volume is $\$ 18.00$ per article (or portion thereof), which should be paid directly to the Copyright Clearance Center (CCC), 222 Rosewood Drive, Danvers, MA 01923. Payment may also be made electronically through CCC Online at copyright.com. Other copying for republication, resale, advertising or promotion, or any form of systematic or multiple reproduction of any material in this book is prohibited except with permission in writing from the publisher. The CCC fee code is 0277-786X/08/\$18.00.

Printed in the United States of America.

Publication of record for individual papers is online in the SPIE Digital Library.

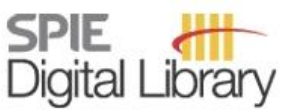

SPIEDigitalLibrary.org

Paper Numbering: Proceedings of SPIE follow an e-First publication model, with papers published first online and then in print and on CD-ROM. Papers are published as they are submitted and meet publication criteria. A unique, consistent, permanent citation identifier (CID) number is assigned to each article at the time of the first publication. Utilization of CIDs allows articles to be fully citable as soon they are published online, and connects the same identifier to all online, print, and electronic versions of the publication. SPIE uses a six-digit CID article numbering system in which:

- The first four digits correspond to the SPIE volume number.

- The last two digits indicate publication order within the volume using a Base 36 numbering system employing both numerals and letters. These two-number sets start with $00,01,02,03,04,05$, $06,07,08,09,0 \mathrm{~A}, 0 \mathrm{~B} \ldots \mathrm{OZ}$, followed by 10-1Z, 20-2Z, etc.

The CID number appears on each page of the manuscript. The complete citation is used on the first page, and an abbreviated version on subsequent pages. Numbers in the index correspond to the last two digits of the six-digit CID number. 


\section{Contents}

vii Conference Committee
ix Introduction

SESSION 1 WETLANDS AND LAKE HABITATS

710402 Space-based ornithology: studying bird migration and environmental change in North America (Invited Paper) [7104-01]

J. A. Smith, NASA Goddard Space Flight Ctr. (United States); J. L. Deppe, Univ. of Maryland, Baltimore County (United States)

710403 Extraction of mangrove forests using a satellite image and a digital elevation model [7104-02]

M. Tamura, K. Kikushima, Kyoto Univ. (Japan)

710404 Effect of abiotic and biotic factors on the abundance of waterbirds in Grado-Marano Lagoon (Italy) [7104-03]

A. Altobelli, T. Hubina, S. Sponza, A. Sisto, Univ. of Trieste (Italy)

$710405 \quad$ Lake Chapala change detection using time series [7104-04]

A. López-Caloca, F.-O. Tapia-Silva, Ctr. de Investigación en Geografía y Geomática (Mexico); B. Escalante-Ramírez, Univ. Nacional Autónoma de México (Mexico)

710406 Lake Izabal (Guatemala) shoreline detection and inundated area estimation from ENVISAT ASAR images [7104-05]

C. Medina, J. Gomez-Enri, J. J. Alonso, P. Villares, Univ. of Cadiz (Spain)

\section{SESSION $2 \quad$ MONITORING LAND USE CHANGE}

710407 Monitoring the urban expansion of Sparta and Nafplio cities using remote sensing and GIS techniques [7104-06]

A. D. Zervakou, K. G. Nikolakopoulos, P. I. Tsombos, G. P. Papanikolaou, Institute of Geology \& Mineral Exploration (Greece)

710408 Urban/periurban vegetation cover dynamics estimation from remotely-sensed data [7104-07]

M. A. Zoran, National Institute of R\&D for Optoelectronics (Romania); C. H. Weber, Univ. Louis Pasteur, Lab. Image E† Ville, CNRS (France)

710409 Analysing land cover change using time series analysis of Landsat data and geoinformation processing: a natural experiment in Northern Greece [7104-08] A. Röder, M. Stellmes, J. Hill, Univ. Trier (Germany); T. Kuemmerle, Humboldt Univ. (Germany); G. M. Tsiourlis, National Agricultural Research Foundation (Greece) 
7104 OA Satellite remote sensing as a tool for monitoring vegetation seasonality [7104-10] B. A. O'Connor, N. Dwyer, Coastal and Marine Resources Ctr. (Ireland); F. Cawkwell, Univ. College Cork (Ireland)

7104 OC Mapping vegetation cover of grassland ecosystem for desertification monitoring in Hulun Buir of Inner Mongolia, China [7104-14]

Z. Qin, Institute of Agro-Resources and Regional Planning (China) and Nanjing Univ. (China); Y. Zhu, Nanjing Univ. (China); W. Li, B. Xu, Institute of Agro-Resources and Regional Planning (China)

\section{SESSION 4 SOIL MOISTURE AND HYDROLOGY}

7104 OD Exploiting optical E.O. data for soil moisture retrieval [7104-15]

K. Richter, G. D'Urso, M. Palladino, Univ. degli Studi di Napoli Federico II (Italy); F. Vuolo, ARIESPACE s.r.I. (Italy)

7104 OE Northern and southern alpine regions snow extent extraction: long-term analysis 1985-2007 [7104-16]

P. Gamba, G. Lisini, L. Natale, E. Sirtori, Univ. degli Studi di Pavia (Italy)

7104 OF Estimation of the Douro River plume dimension based on image segmentation of MERIS scenes [7104-17]

A. Teodoro, H. Gonçalves, F. Veloso-Gomes, J. A. Gonçalves, Univ. do Porto (Portugal)

7104 OG Airborne remote sensing applications in hydrology and water resources [7104-19] C. M. U. Neale, Utah State Univ. (United States)

\section{SESSION 5 ESTIMATION OF EVAPOTRANSPIRATION}

$7104 \mathrm{OH}$ Monitoring evapotranspiration at landscape scale in Mexico: applying the energy balance model using remotely sensed data [7104-20]

C. Coronel, E. Rosales, F. Mora, A. A. López-Caloca, F.-O. Tapia-Silva, Research Ctr. in Geography and Geomatics (Mexico); G. Hernández, Univ. Autonoma Metropolitana (Mexico)

7104 Ol Estimating irrigation demand using satellite remote sensing: a case study of Paphos District area in Cyprus [7104-21]

D. G. Hadjimitsis, G. Papadavid, K. Themistokleous, Cyprus Univ. of Technology (Cyprus);

A. Kounoudes, SignalGeneriX Ltd. (Cyprus); L. Toulios, National Agricultural Research Foundation (Greece)

$71040 \mathrm{~J}$ Spatial sharpening of land surface temperature for daily energy balance applications [7104-22]

C. Cammalleri, G. Ciraolo, M. Minacapilli, Univ. degli Studi di Palermo (Italy)

7104 OK A sensitivity analysis of a surface energy balance model to LAI (Leaf Area Index) [7104-23] A. Maltese, M. Cannarozzo, F. Capodici, G. La Loggia, T. Santangelo, Univ. degli Studi di Palermo (Italy) 
$7104 \mathrm{OL}$ The comparison of regional evapotranspiration estimation with NOAA/AVHRR and MODIS data [7104-24]

W. Wang, Renmin Univ. of China (China); L. Sun, Beijing Normal Univ. (China); G. Liu,

Renmin Univ. of China (China); R. Sun, Beijing Normal Univ. (China)

\section{SESSION 6 OTHER APPLICATIONS}

$71040 \mathrm{~N}$ Identification of tree species from high-resolution satellite imagery by using crown parameters [7104-26]

C. Kim, S.-H. Hong, Kookmin Univ. (Korea, Republic of)

7104 OP Mapping irrigation area of winter wheat farmland in North China Plain using MODIS remote sensing data [7104-28]

L. Lin, Nanjing Univ. (China); Z. Qin, Nanjing Univ. (China) and Institute of Agro-Resources and Regional Planning (China); J. Li, Nanjing Univ. (China)

\section{SESSION 7 VEGETATION MONITORING II}

7104 OR Recent trends in agricultural production of Africa based on AVHRR NDVI time series [7104-30]

A. Vrieling, Joint Research Ctr. of the European Commission (Italy); K. M. de Beurs, Virginia Polytechnic Institute and State Univ. (United States); M. E. Brown, Science Systems and Applications, Inc., NASA Goddard Space Flight Ctr. (United States)

7104 OT Dryland observation at local and regional scale: comparison of Landsat TM and NOAA AVHRR time series [7104-33]

M. Stellmes, Univ. Trier (Germany); T. Udelhoven, Ctr. de Recherche Public-Gabriel Lippmann (Luxembourg); A. Röder, J. Hill, Univ. Trier (Germany)

7104 OU Analysing spatio-temporal pattern of changing farmland in China's arid zone [7104-34] Q. Zhou, B. Sun, Hong Kong Baptist Univ. (Hong Kong, China)

\section{SESSION 8 CROP YIELD MONITORING}

7104 OV Imaging spectroscopy for estimating sugarcane leaf nitrogen concentration [7104-53] E. M. Abdel-Rahman, F. B. Ahmed, Univ. of KwaZulu-Natal (South Africa); M. van den Berg, South African Sugarcane Research Institute (South Africa)

7104 OX RS-CGM: a spatial crop growth model based on GIS and RS [7104-36]

Y. Lei, Institute of Genetics and Developmental Biology (China); T. Tang, Institute of Genetics and Developmental Biology (China) and Graduate Univ. of Chinese Academy of Sciences (China); L. Zheng, Institute of Genetics and Developmental Biology (China); S. Zhang, Z. Wang, Institute of Genetics and Developmental Biology (China) and Graduate Univ. of Chinese Academy of Sciences (China) 
7104 OY Prediction of winter wheat grain protein content by ASTER image [7104-37]

W. Huang, X. Song, J. Wang, National Engineering Research Ctr. for Information

Technology in Agriculture (China); Z. Wang, Agriculture and Agri-Food Canada (Canada);

C. Zhao, National Engineering Research Ctr. for Information Technology in Agriculture

(China)

\section{POSTER SESSION}

$71040 Z$ The assessment of air pollution and climatic changes impacts on mountain forest ecosystems by satellite remote sensing data [7104-38]

M. A. Zoran, National Institute of R\&D for Optoelectronics (Romania); L. F. V. Zoran, Univ. Politechnica of Bucharest (Romania); A. I. Dida, Romsilva RA (Romania)

710410 Rice crop monitoring using X, C and L band SAR data [7104-39]

Y. Suga, Hiroshima Institute of Technology (Japan); T. Konishi, Nihon CADIC Co., Ltd. (Japan)

710411 Comparison of field emissivities with laboratory measurements and ASTER data [7104-40] M. Mira, Univ. of Valencia (Spain); T. Schmugge, New Mexico State Univ. (United States); E. Valor, V. Caselles, C. Coll, Univ. of Valencia (Spain)

710412 Evaluating health of paddy rice field ecosystem with remote sensing and GIS in Lower Yangtze River Plain, China [7104-41]

J. Li, Nanjing Univ. (China); Z. Qin, Nanjing Univ. (China) and Institute of Agro-Resources and Regional Planning (China); W. Li, Institute of Agro-Resources and Regional Planning (China); L. Lin, Nanjing Univ. (China)

710413 Using evapotranspiration estimates from Landsat TM data to analyse uncertainties of a spatially distributed hydrological model (PRMS) [7104-44]

M. Vohland, M. Stellmes, Univ. Trier (Germany)

710414 Snow mapping for water resource management using MODIS satellite data in northern Xinjiang, China [7104-46]

H. Pei, Nanjing Univ. (China); Z. Qin, Nanjing Univ. (China) and Institute of Agro-Resources and Regional Planning (China); S. Fang, Z. Liu, Xinjiang Univ. (China)

710415 Study on the late frost monitoring technology for winter wheat by EOS/MODIS data [7104-47]

X. Zhang, Meteorological Observation Center of CMA (China); L. Sun, R. Sun, Beijing Normal Univ. (China), LRSS (China), and Beijing Key Lab. of Environmental Remote Sensing (China); Q. Guo, Henan Institute of Meteorology (China); W. Wang, Renmin Univ. of China (China)

710416 Study on the spectrum response of rice to the zinc pollution [7104-48]

Q. Cheng, X. WU, Zhejiang Gongshang Univ. (China)

710417 Extracting chlorophyll concentration of water body based on spectral unmixing model [7104-49]

X. Wu, Q. Cheng, Zhejiang Gongshang Univ. (China)

Author Index 


\title{
Conference Committee
}

\author{
Symposium Chairs \\ Guido D'Urso, Università degli Studi di Napoli Federico II (Italy) \\ Steven P. Neeck, NASA Headquarters (United States) \\ Conference Chairs
}

Christopher M. U. Neale, Utah State University (United States)

Manfred Owe, NASA Goddard Space Flight Center (United States)

Guido D'Urso, Università degli Studi di Napoli Federico II (Italy)

Session Chairs

1 Wetlands and Lake Habitats

Christopher M. U. Neale, Utah State University (United States)

2 Monitoring Land Use Change

Christopher M. U. Neale, Utah State University (United States)

3 Vegetation Monitoring I

Katja Richter, Università degli Studi di Napoli Federico II (Italy)

4 Soil Moisture and Hydrology

Guido D'Urso, Università degli Studi di Napoli Federico II (Italy)

5 Estimation of Evapotranspiration

Guido D'Urso, Università degli Studi di Napoli Federico II (Italy)

6 Other Applications

Guido D'Urso, Università degli Studi di Napoli Federico II (Italy)

$7 \quad$ Vegetation Monitoring II

Katja Richter, Università degli Studi di Napoli Federico II (Italy)

8 Crop Yield Monitoring

Christopher M. U. Neale, Utah State University (United States) 
Downloaded From: https://www.spiedigitallibrary.org/conference-proceedings-of-spie on 25 Apr 2023

Terms of Use: https://www.spiedigitallibrary.org/terms-of-use 


\section{Introduction}

This proceedings volume contains papers presented during the conference on Remote Sensing for Agriculture, Ecosystems, and Hydrology X. The conference was part of the 15th International Symposium on Remote Sensing sponsored by SPIE Europe. The symposium was held at the University of Wales Institute in Cardiff, Wales, 15 through 18 September 2008.

The conference is dedicated to providing rapid dissemination of scientific and technical information, and attracted scientists and professionals from throughout Europe, Africa, Asia, and the Americas. More than 40 oral and poster presentations were given, covering a broad range of topics in the field of remote sensing applications in environmental science.

The program was organized according to major themes, with sessions on Agriculture: Canopy and Crop Yield Monitoring and Applications such as Monitoring Land Use Change; Ecosystems: Wetland and Lake Habitat Monitoring, Natural Vegetation Monitoring; Hydrology: Soil Moisture, Hydrology and Climate Applications, Evapotranspiration, and Energy Balance Estimation using Remote Sensing. The poster presentations also had good representation from the three major themes. The presentations described both fundamental and applicationsbased research activities from modeling, to laboratory and field experiments, to operational applications.

We extend our thanks to the presenters for their efforts and to the participants for their insightful questions and discussions. Special thanks are also due to the host city for the excellent venue and to the SPIE organizational staff for their support prior to, during, and after the symposium. We look forward to an even more successful and exciting conference in 2009. 
Downloaded From: https://www.spiedigitallibrary.org/conference-proceedings-of-spie on 25 Apr 2023

Terms of Use: https://www.spiedigitallibrary.org/terms-of-use 